\title{
Tooth Cell
}

National Cancer Institute

\section{Source}

National Cancer Institute. Tooth Cell. NCI Thesaurus. Code C33793.

The cell of the tooth. It includes the odontoblast, cementoblast, cementocyte, and ameloblast. 